 \\ doi:10.20396/revpibic2620181400
}

\section{Dinâmicas atuais da urbanização na Região Metropolitana de Campinas e as disputas de narrativas sobre o urbano}

\section{Bárbara Ramos Azalim*, Dayane Araújo de Oliveira, Fabiana de Brito Matiello, Gabriela Borges Soares, Isabelly Thives Knupfer Santos, Vinícius Villela da Silva, Isadora Garcia, André Pasti}

\section{Resumo}

A pesquisa busca analisar diversos aspectos do processo contemporâneo de urbanização da Região Metropolitana de Campinas (RMC), vinculando a análise da urbanização à compreensão das disputas de narrativas sobre o urbano.

\section{Palavras-chave: \\ Região Metropolitana de Campinas, urbanização corporativa, imaginário urbano.}

\section{Introdução}

A pesquisa buscou analisar aspectos da urbanização da $\mathrm{RMC}$ e as disputas de narrativas sobre o urbano. Buscouse dar ênfase às contradições que acompanham a lógica predominante de empresariamento urbano e urbanização corporativa (SANTOS, 2008; SÁNCHEZ, 2015), como o aprofundamento das desigualdades socioespaciais. Também foram investigados conflitos urbanos frutos do choque dessa lógica com projetos alternativos, englobando a luta por direitos e as resistências dos pobres na economia urbana. A pesquisa analisa as disputas de discursos e narrativas sobre o urbano na RMC a partir de diferentes dimensões - que foram concretizadas em cada sub-projeto de pesquisa dos alunos integrantes.

\section{Resultados e Discussão}

Dentro da lógica da cidade-mercadoria, o planejamento urbano de Campinas vem utilizando estratégias de city marketing alinhadas com imaginário de uma cidade eficiente (aos negócios), "inovadora" e "surpreendente". Nessa cidade-empresa, os conflitos são invisibilizados, pois seria necessário vender a cidade como fruto de um suposto consenso (SÁNCHEZ, 2015). Ao analisar peças de city marketing, foi possível observar a exaltação dos espaços voltados ao capital e ausências de parcelas da cidade onde a cidadania não é exercida. Uma das ações analisadas foi o projeto de revitalização da Av. Francisco Glicério, investigando elementos de gentrificação no centro. Em várias das intervenções atuais, o paradigma de direitos está ausente dos discursos oficiais das peças de planejamento que promovem a imagem da cidade. Ao mesmo tempo, os conflitos por moradia e serviços básicos se aprofundam no espaço urbano, como foi analisado para o caso da região do Jardim Campo Belo.

Essa perspectiva da cidade-mercadoria é predominante na RMC, e acompanha uma grande segregação urbana. O imaginário dessas cidades segregadas é marcado pela lógica de condomínio (DUNKER, 2015). Ao analisar a cidade de Vinhedo, observou-se diversos elementos que, simultaneamente, são produto e reproduzem essa lógica de condomínio - do discurso da segurança à negação do outro, passando pela estigmatização das regiões periféricas da cidade como lugares da violência e barbárie. Entre os agentes da produção desse imaginário urbano, ganha destaque o mercado imobiliário da região. A investigação de peças de empreendimentos de grande porte - como o complexo de condomínios Swiss Park e os maiores shopping centers da região - permitiu desvendar algumas das estratégias da lógica desse imaginário, que passa pela busca da exclusividade e da promoção da segregação como virtude.

São muitos os conflitos gerados a partir da segregação promovida pela urbanização corporativa - como no caso da moradia (SILVA, GARCIA, PASTI, 2018). Foram analisados o policiamento e o acesso à energia elétrica como elementos dessa segregação. A energia elétrica é cada vez mais necessária às atividades do circuito inferior da economia das cidades (MESTRE, 2017). Ao não ser promovida como um direito, observa-se a difusão de contrarracionalidades como "gatos elétricos", que apresentam alternativa criativa ao sistema político e econômico vigente na cidade (FONSECA, 2014). O policiamento é um uso do território que também reproduz desigualdades. A geografia dos fixos do policiamento e dos crimes permite questionar sobre as prioridades da atuação policial, já que há disparidades entre a localização de crimes graves e a concentração da atividade policial, além de uma desigualdade do medo parte da cidade teria medo dos pobres, enquanto outra parte, medo da violência policial (MELGAÇO, 2005).

\section{Conclusão}

As narrativas dominantes sobre o urbano na RMC são marcadas pela lógica de condomínio, pela promoção da cidade como mercadoria e pela defesa da segregação como virtude. Por outro lado, é notável o silenciamento dos conflitos gerados pela ausência de cidadania na cidade, decorrente, também, da priorização das intervenções voltadas às empresas e aos consumidores.

\section{Agradecimentos}

Ao $\mathrm{CNPq}$, à equipe do PIBIC-EM e à Direção do Cotuca.

MELGAÇO, L. A geografia do atrito: dialética espacial e violência em Campinas - SP. 2005. Dissertação (Mestrado) - USP, 2005.

MESTRE, A. P. Novos contextos urbanos periféricos: um diálogo entre o consumo produtivo de energia elétrica e o circuito inferior da economia urbana na metrópole paulista. In: ARROYO, M; CATAIA, M; DANTAS, A (org.). Dos circuitos da economia urbana aos circuitos espaciais de produção. Natal/RN: Sebo Vermelho, 2017.

FONSECA, H. R. O recente processo de urbanização da cidade de Campinas-SP (1990-2014). 2014.

DUNKER, C. I. L. Mal-estar, sofrimento e sintoma: uma psicopatologia do Brasil entre muros. São Paulo: Boitempo, 2015.

SÁNCHEZ, F. A reinvenção das cidades para um mercado mundial. Chapecó: Editora Argos, 2015.

SANTOS, M. A Urbanização Brasileira. São Paulo: Edusp, 2008.

SILVA, A.; GARCIA, I; PASTI, A. Ocupação Vila Soma (Sumaré/SP): resistência à cidade corporativa e luta pela cidadania territorial. Boletim Campineiro de Geografia, v. 7, n. 2, 2018. 